\title{
O direito de acesso à justiça do consumidor superendividado: (in)efetividade do processo e soluções consensuais de conflitos
}

\author{
The over-indebted consumer's right to access justice: (in)effectiveness of the process and \\ consensual conflict solutions
}

Augusto de Paiva Siqueira*

Vitor Hugo do Amaral Ferreira**

\section{REFERÊNCIA}

SIQUEIRA, Augusto; Ferreira, Vitor. O Direito de Acesso à Justiça do Consumidor Superendividado: (In)Efetividade do Processo e Soluções Consensuais de Conflitos. Revista da Faculdade de Direito da UFRGS, Porto Alegre, n. 45, p. 154-185, abr. 2021. DOI: https://doi.org/10.22456/0104-6594.107938.

\section{RESUMO}

O presente artigo se propõe a analisar o tratamento jurídico do superendividamento a partir do direito fundamental de acesso à justiça. Serão analisados o fenômeno do superendividamento na sociedade contemporânea, seus efeitos sobre a relação de consumo e as disposições legais pertinentes ao tema. Em seguida, será abordado o acesso à justiça sob a óptica do Direito do Consumidor, investigando o papel do Estado no enfrentamento desta problemática. Ao final, após a revisão crítica da bibliografia e da jurisprudência, será ponderada a efetividade da proteção do consumidor superendividado, assim como a possibilidade de utilização de métodos alternativos de solução de conflitos para o enfrentamento do problema.

\section{PALAVRAS-CHAVE}

Acesso à justiça. Direito do Consumidor. Superendividamento.

\begin{abstract}
This article intends to analyze the legal treatment of over-indebtedness by the agency of the constitutional safeguard of ample access to justice. Therefore, the over-indebtedness phenomena in contemporary society and its ramifications on the consumption relations and its statutory provisions will be analyzed. Subsequently, it will address the guarantee of access to justice under the optics of consumer rights, investigating the role of the State in the confrontation of this issue. At the end, after the critical review of the bibliography and case law, the article will reflect on the effectiveness of over-indebted customer protection, as well as the possibility of using the alternative methods of conflict resolution to face this problem.
\end{abstract}

\section{KEYWORDS}

Ample access to justice. Consumer rights. Over-indebtedness.

\section{SUMÁRIO}

1. Introdução. 2. Superendividamento e o mínimo existencial. 3. Do regime jurídico da insolvência do consumidor pessoa física. 4. Superendividamento do consumidor e jurisprudência. 5. Acesso à ordem jurídica justa e a utilização de métodos alternativos de solução de conflitos. 6. Projeto de Lei n. 3.515 de 2015 do Senado Federal: outras perspectivas. 7. Conclusão. Referências. Dados da publicação.

\footnotetext{
* Advogado. Especialista em Direito do Consumidor (UFG) e pós-graduando em Direito Público (UFG). Graduado em Direito pela Escola de Direito e Relações Internacionais da PUC-GO.

** Doutorando em Direito (PPGD-UFRGS).
} 


\section{INTRODUÇÃO}

A Constituição Federal de 1988 trouxe a defesa do consumidor como direito e garantia fundamental (art. $5^{\circ}$, inciso XXXII ${ }^{1}$ ), consagrando-a como princípio da ordem econômica (art. 170, inciso $\mathrm{V}^{2}$ ). Nessa perspectiva, é possível constatar na atual Constituição maior proteção jurídica ao sujeito vulnerável da relação de consumo, especialmente em razão do desnivelamento jurídico, característico das avenças entre consumidores e fornecedores. Contudo, embora ampliada a tutela constitucional, a sociedade de consumo contemporânea tem presenciado o crescente aumento do fenômeno do superendividamento diante da ampliação da oferta de crédito ao consumidor.

Embora exista o dever do Estado de assumir o protagonismo com relação a proteção dos consumidores, o Direito brasileiro não dispõe de instrumentos jurídicos suficientes para garantir a tutela do mínimo existencial ao consumidor superendividado. Essa lacuna não só compromete a observância do princípio da dignidade da pessoa humana e o direito de acesso à justiça, mas também a própria satisfação do crédito dos agentes econômicos.

Nessa perspectiva, este ensaio tem por objetivo abordar o fenômeno do superendividamento a partir da Constituição Federal e dos princípios aplicáveis à tutela dos consumidores, investigando a efetividade das disposições legais no ordenamento jurídico e os instrumentos que habilitem uma proposição ao problema.

\footnotetext{
1 “Art. $5^{\circ}$ Todos são iguais perante a lei, sem distinção de qualquer natureza, garantindo-se aos brasileiros e aos estrangeiros residentes no País a inviolabilidade do direito à vida, à liberdade, à igualdade, à segurança e à propriedade, nos termos seguintes: [...] XXXII - o Estado promoverá, na forma da lei, a defesa do consumidor." 2 "Art. 170. A ordem econômica, fundada na valorização do trabalho humano e na livre iniciativa, tem por fim assegurar a todos existência digna, conforme os ditames da justiça social, observados os seguintes princípios: [...] V - defesa do consumidor."
} 


\title{
2 SUPERENDIVIDAMENTO E O MÍNIMO EXISTENCIAL
}

A percepção do superendividamento como fenômeno multifacetado, diante da ordem social $^{3}$, econômica ${ }^{4}$, comportamental ${ }^{5}$ e jurídica ${ }^{6}$, é essencial para transpor as barreiras de acesso à ordem jurídica. Desse modo, é oportuno compreender os paradigmas da sociedade de consumo pós-moderna em relação à concessão de crédito e ao consequente superendividamento. Com conceito ainda em definição pela legislação brasileira ${ }^{7}$, esse

\begin{abstract}
${ }^{3}$ Entre os pioneiros a tratar do tema, LOPES, José Reinaldo de Lima. Crédito ao consumo e superendividamento: uma problemática geral. Revista de Direito do Consumidor. São Paulo, v. 17, p. 57-64, jan./mar, 1996; COSTA, Geraldo de Faria Martins. Superendividamento: a proteção do consumidor de crédito em direito comparado brasileiro e francês. São Paulo: Revista dos Tribunais, 2002; e CASADO, Márcio Mello. Os princípios fundamentais como ponto de partida para uma primeira análise do sobre-endividamento no Brasil. Revista de Direito do Consumidor, São Paulo, v. 33, p. 130-140, 2000.

4 Ao aspecto econômico, KILBORN, Jason J. Comportamentos Econômicos, superendividamento; estudo comparativo da insolvência do consumidor: buscando as causas e avaliando soluções. In: MARQUES, Claudia Lima; CAVALLAZZI, Rosângela (coords.). Direitos do Consumidor Endividado: superendividamento e crédito. São Paulo: Editora Revista dos Tribunais, 2006, p. 66-104. Ver também BRAUNER, Daniela Corrêa Jacques. Estudo, mercado e defesa do consumidor: uma leitura da proteção constitucional ao consumidor superendividado à luz da intervenção do Estado na ordem econômica. Revista de Direito do Consumidor, São Paulo, a. 24, v. 96, nov./dez. 2014. Ainda sobre o recorte econômico do superendividamento "em março de 2015, segundo dados do Banco Central (BC), o estoque de crédito consignado no sistema financeiro chegou a R $\$ 259$ bilhões, expansão de 13\% em 12 meses. Em aproximadamente uma década, o montante financiado aumentou 382\%”. OLIVEIRA, Janaína. Empréstimo Consignado dispara na crise. Hoje em dia, Belo Horizonte, 17 maio 2015. Disponível em: http://www.hojeemdia.com.br/noticias/economia-e-negocios/empréstimo-consignado-dispara-na-crise-1.318637.
\end{abstract} Acesso em: 31 mar. 2021.

5 Ver DUQUE, Marcelo Schenk. O dever fundamental do Estado de proteger a pessoa da redução da função cognitiva provocada pelo superendividamento. Revista de Direito do Consumidor, São Paulo, n. 73, p. 157-179, 2014; CARVALHO, Diógenes Faria de; OLIVEIRA, Amanda Flávio. Vulnerabilidade comportamental do consumidor: por que é preciso proteger a pessoa superendividada? In: MIRAGEM, Bruno; MARQUES, Claudia Lima; OLIVEIRA, Amanda Flávio de (coords.). 25 anos do Código de Defesa do Consumidor: trajetória e perspectiva. São Paulo: Editora Revista dos Tribunais, 2016, p. 527-548; Felicidad financiada: la sociedad de consumo frente el crédito, artigo que escrevo em co-autoria com o professor Diógenes Faria de Carvalho (CARVALHO, Diógenes Faria de; SANTOS, Nivaldo. A vulnerabilidade psíquica e o superendividamento do consumidor. In: CARVALHO, Diógenes Faria; SANTOS; Nilvaldo; FERREIRA, Vitor Hugo do Amaral (org.). Sociedade de Consumo: pesquisas em direito do consumidor. Goiânia: Espaço Acadêmico, 2015, p. 49-78); CARVALHO, Diógenes Faria de; SANTOS, Nivaldo. A vulnerabilidade psíquica e o superendividamento do consumidor. In: CARVALHO, Diógenes Faria; SANTOS; Nilvaldo; FERREIRA, Vitor Hugo do Amaral (org.). Sociedade de Consumo: pesquisas em direito do consumidor. Goiânia: Espaço Acadêmico, 2015, p. 89-112.

6 Nessa percepção, professora Claudia Lima Marques em: Sugestões para uma lei sobre o tratamento do superendividamento de pessoas físicas em contratos de crédito ao consumo: proposições com base em pesquisa empírica de 100 casos no Rio Grande do Sul (MARQUES, Claudia Lima. Sugestões para uma lei sobre o tratamento do superendividamento de pessoas físicas em contratos de crédito ao consumo: proposições com base em pesquisa empírica de 100 casos no Rio Grande do Sul. In: MARQUES, Claudia Lima; CAVALLAZZI, Rosângela Lunardelli (coords.). Direitos do consumidor endividado: superendividamento e crédito. São Paulo: Editora Revista dos Tribunais, 2006, p. 255-309; MARQUES, Cláudia Lima. Algumas perguntas e respostas sobre a prevenção e tratamento do superendividamento dos consumidores pessoas físicas. Revista de Direito do Consumidor, São Paulo, v. 75, n. 9, 2010). Veja também LIMA, Clarissa Costa de; BERTONCELLO, Káren Rick Danilevicz; MARQUES, Claudia Lima. Anteprojeto de lei dispondo sobre a prevenção e o tratamento das situações de superendividamento de consumidores pessoas físicas de boa-fé. Revista de Direito do Consumidor, São Paulo, v. 73, p. 345-367, 2010.

7 Projeto de Lei n. 1.166/2020, que estabeleceu teto para todas as modalidades de crédito ofertadas por meio de cartões de crédito e cheque especial, veda a cobrança de juros e multas por atraso no pagamento das prestações de

SIQUEIRA, Augusto; Ferreira, Vitor. O Direito de Acesso à Justiça do Consumidor Superendividado: (In)Efetividade do Processo e Soluções Consensuais de Conflitos.Revista da Faculdade de Direito da UFRGS, Porto Alegre, n. 45, p. 154-185, abr. 2021. ISSN: 0104-6594. E-ISSN: 2595-6884. DOI: https://doi.org/10.22456/0104-6594.107938. 
fenômeno é um dos principais problemas do mercado contemporâneo, decorrente da expansão da cultura de consumo - em que o padrão de aquisição passa a estar vinculado a uma identificação do sujeito como pertencente a certa classe social - além de ter sido potencializado, nas últimas décadas, pela facilidade de acesso ao crédito.

Como já se assegurou em textos anteriores, o fenômeno é característico da sociedade moderna, destacando a progressiva ressignificação do consumo e o enaltecimento do "ter". O valor que se tinha em relação ao trabalho como fonte criativa e criadora, cedeu lugar para alienação do consumo e as facilidades que o envolvem. A expressão 'consumista' vem agregada à aquisição do supérfluo, sem conotação de culpa; ao contrário, significando qualidade superior em relação àqueles que necessariamente não tem. "Ter” passa a relacionar-se com prazer, com importância e com pertencimento social. Trata-se de um critério invertido que passa a ser acolhido pela sociedade. Para se ter uma noção mais abrangente da proporção que os atos consumistas tomaram, há que se destacar seus reflexos no indivíduo e no coletivo social. As ações por impulso, ainda que indiretamente, podem atingir a massa social, na medida em que o comportamento de um se torna moda e hábitos mudam ${ }^{8}$.

A doutrina tem assumido o papel de conceituar o fenômeno do superendividamento do consumidor. Para Claudia Lima Marques, o sobreendividamento é a "impossibilidade global do devedor pessoa física, consumidor, leigo e de boa-fé de pagar todas as suas dívidas atuais e futuras de consumo (excluídas as dívidas com o Fisco, oriundas de delitos e de alimentos)"9. Refere-se, portanto, ao endividado cujas dívidas contraídas são exclusivamente oriundas da relação de consumo, não abrangendo aquelas advindas de débitos tributários, prestações alimentícias ou de ilícitos civis e penais. Não só isso, mas refere-se unicamente ao endividado

operações de crédito e de compras de produtos e serviços, para todas as dívidas contraídas durante a vigência do estado de calamidade pública, o art. $2^{\circ}, \S 1^{\circ}$, definiu o conceito legal de superendividamento, "entende-se por superendividado a impossibilidade manifesta de o consumidor, pessoa natural, de boa-fé, pagar a totalidade de suas dívidas de consumo, exigíveis e vincendas, sem comprometer seu mínimo existencial, nos termos da regulamentação" (BRASIL. Senado Federal. Projeto de Lei do Senado n. 1.166/20. Autor: Senador Alvaro Dias PODEMOS/PR. Estabelece teto de $20 \%$ ao ano para todas as modalidades de crédito ofertadas por meio de cartões de crédito e cheque especial para todas as dívidas contraídas entre os meses de março de 2020 e julho de 2021. Situação: tramitação encerrada. Disponível em: https://www25.senado.leg.br/web/atividade/materias//materia/141297. Acesso em: 31 mar. 2021).

${ }^{8}$ CARVALHO, Diógenes Faria de; FERREIRA, Vitor Hugo do Amaral. Consumo(ismo) e (super)endividamento: (des)encontros entre a dignidade e a esperança. In: MARQUES, Claudia Lima; CAVALLAZZI, Rosângela; LIMA, Clarissa Costa de (coords.). Direitos do Consumidor endividado II: vulnerabilidade e inclusão. São Paulo: Revista dos Tribunais, 2016, v. 2, p. 171-198, p. 177.

${ }^{9}$ MARQUES, Claudia Lima. Sugestões para uma lei sobre o tratamento do superendividamento de pessoas físicas em contratos de crédito ao consumo: proposições com base em pesquisa empírica de 100 casos no Rio Grande do Sul. In: MARQUES, Claudia Lima; CAVALLAZZI, Rosângela Lunardelli (coords.). Direitos do consumidor endividado: superendividamento e crédito. São Paulo: Revista dos Tribunais, 2006, p. 255-309, p. 256. 
pessoa física, restringindo o alcance da definição de consumidor prevista no art. $2^{\circ}$ do Código de Defesa do Consumidor $(\mathrm{CDC})^{10}$. A ressalva é justificada porque a insolvência das pessoas jurídicas já encontra regulamentação pelo Código Civil (CC), ao passo que as sociedades empresárias se sujeitam à Lei n. 11.101/05, a qual regula os procedimentos de falência e recuperação judicial e extrajudicial.

Assim, esse perfil específico de endividado é ilustrado por aquele indivíduo que se insere no mercado de consumo atraído pela oferta, publicidade e notadamente pela facilidade de acesso ao crédito para, imbuído de boa-fé, contratar com credores a fim de realizar as suas necessidades e satisfazer os seus anseios pessoais por meio do consumo de produtos e serviços. Há ainda autores que buscam uma diferenciação entre as espécies de superendividamento, destacando as modalidades ativa e passiva. Sobre o assunto, elucida a autora portuguesa Maria Manuel Leitão Marques:

[o] sobreendividamento pode ser activo, se o devedor contribui activamente para se colocar em situação de impossibilidade de pagamento, por exemplo, não planeando os compromissos assumidos e procedendo a uma acumulação exagerada de créditos em relação aos rendimentos efetivos e esperados; ou passivo, quando circunstâncias não previsíveis (desemprego, precarização do emprego, divórcio, doença ou morte de um familiar, acidente, etc.) afectam gravemente a capacidade de reembolso do devedor, colocando-o em situação de impossibilidade de cumprimento. ${ }^{11}$

Seguindo a linha de pensamento da doutrinadora, o endividamento excessivo pode decorrer de comportamentos protagonizados pelo próprio consumidor, ocasião em que ele age voluntariamente de forma não planejada ou por meio do abuso do seu direito de crédito (superendividamento ativo). Igualmente, também pode decorrer de causa acidental, quando consequente de fatores imprevisíveis ou eventos adjacentes - como o desemprego - capazes de impactar significativamente a sua solvabilidade (superendividamento passivo).

Em todo o caso, o que se coloca em risco são direitos mínimos do consumidor e, por via de consequência, a própria dignidade da pessoa humana (art. $1^{\circ}$, inciso III da Constituição Federal $^{12}$ ). Com o acúmulo excessivo de dívidas, o sujeito de direito coloca o seu patrimônio à mercê dos débitos contraídos, além de se ver compelido a se retirar do mercado de consumo, sob pena de sacrificar prestações indispensáveis à sua subsistência digna. Noutro lado, a

\footnotetext{
10 “Art. $2^{\circ}$ Consumidor é toda pessoa física ou jurídica que adquire ou utiliza produto ou serviço como destinatário final. Parágrafo único. Equipara-se a consumidor a coletividade de pessoas, ainda que indetermináveis, que haja intervindo nas relações de consumo.”

11 LEITÃO MARQUES, Maria Manuel. O endividamento dos consumidores. Lisboa: Almedina, 2000, p. 2.

12 "Art. $1^{\circ}$ A República Federativa do Brasil, formada pela união indissolúvel dos Estados e Municípios e do Distrito Federal, constitui-se em Estado Democrático de Direito e tem como fundamentos: [...] III - a dignidade da pessoa humana."
} 
proteção do consumidor superendividado é paradigma consentâneo com os objetivos republicanos previstos na Lei Maior, a exemplo da busca pela construção de uma sociedade livre, justa e solidária e a redução das desigualdades sociais e regionais (art. $3^{\circ}$ da Constituição Federal $^{13}$ ).

Nessa perspectiva, Claudia Lima Marques alerta a respeito da necessidade de prevenção ao superendividamento ao considerar a potencialidade do fenômeno como causador de exclusão social. Para a doutrinadora:

[o] "superendividamento" é uma crise de solvência e de liquidez do consumidor (com reflexos em todo o seu grupo familiar), crise que facilmente resulta em sua exclusão total do mercado de consumo, comparável a uma nova espécie de "morte civil" (SULLIVAN; WARREN; WESTBROOK, 1989): a "morte do homo economicus" (LORENZETTI; MARQUES, 2005). Prevenir tal efeito negativo da sociedade de consumo atual e do acesso ao crédito é o melhor dos caminhos ${ }^{14}$.

A questão do endividamento excessivo ganha relevo constitucional quando ponderada a partir da garantia de que o Estado deverá promover a defesa do consumidor na forma do artigo $5^{\circ}$, inciso XXXII e do artigo 170, ambos da Constituição Federal (CF). Não é por outra razão que José Afonso da Silva interpreta que a defesa do consumidor prevista em texto constitucional tem “[...] o relevante efeito de legitimar todas as medidas de intervenção estatal necessárias a assegurar a proteção prevista. Isso naturalmente abre larga brecha na economia de mercado, que se esteia, em boa parte, na liberdade de consumo [...]"15.

Assim, a relevância do direito constitucional do consumidor autoriza no constitucionalismo contemporâneo a aplicação direta da Constituição às relações de consumo para garantir a máxima efetividade da tutela a ser prestada pelo Estado, em especial nas situações de superendividamento. Por esse motivo, não se pode perder de vista na interpretação da legislação infraconstitucional os preceitos estampados na Carta Republicana, destacadamente a dignidade da pessoa humana e os direitos e liberdades fundamentais. A respeito da constitucionalização do direito privado, interpreta Ingo Sarlet:

\footnotetext{
13 “Art. $3^{\circ}$ Constituem objetivos fundamentais da República Federativa do Brasil: I - construir uma sociedade livre, justa e solidária; II - garantir o desenvolvimento nacional; III - erradicar a pobreza e a marginalização e reduzir as desigualdades sociais e regionais; IV - promover o bem de todos, sem preconceitos de origem, raça, sexo, cor, idade e quaisquer outras formas de discriminação."

14 MARQUES, Claudia Lima. Consumo como igualdade e inclusão social: a necessidade de uma lei especial para prevenir e tratar o "superendividamento" dos consumidores pessoas físicas. Revista Jurídica da Presidência, Brasília, v. 13. n. 101, p. 405-424, out. 2011/jan. 2012, p. 408.

15 SILVA, José Afonso da. Curso de Direito Constitucional positivo. 23ª ed. São Paulo: Malheiros, 2004, p. 261 262.
} 
[i]sso significa, em última análise, que as normas de direito privado não podem contrariar o conteúdo dos direitos fundamentais, impondo-se uma interpretação das normas privadas (infraconstitucionais) conforme os parâmetros axiológicos contidos nas normas de direitos fundamentais, o que habitualmente ocorre quando se trata de aplicar conceitos indeterminados e cláusulas gerais ${ }^{16}$.

Na mesma direção, Carlos Eduardo Dieder Reverbel pontua a respeito da eficácia horizontal dos direitos fundamentais às relações de consumo como importante fator de equilíbrio na relação contratual. Para o jurista:

[a] preocupação da eficácia horizontal dos Direitos Fundamentais nas relações privadas nasce justamente quando, uma relação de direito privado, uma das partes, ao se exceder na liberdade de contratar, viola direito fundamental ordinário do outro contraente. O Estado, como terceiro imparcial, tem o dever de regular as relações contratuais, bem como o dever de fiscalizar/tutelar a esfera de liberdade e de direitos dos contratantes, evitando tratamento degradante, desumano e violador das liberdades fundamentais ${ }^{17}$.

Na hipótese do superendividamento, o dever constitucional do Estado de promover a defesa dos consumidores acaba por exigir a aplicação imediata da Constituição. Este raciocínio se apoia no conteúdo prestacional do princípio da dignidade da pessoa humana, o qual transfere ao Estado uma missão protetiva e assistencial, possibilitando o pleno exercício e fruição da dignidade naquilo que o indivíduo necessita da atividade estatal para a realização e proteção de suas necessidades existenciais básicas.

Interessante destacar que o argumento da aplicação imediata da Constituição não é utilizado para legitimar a interferência irrestrita do Estado nos contratos privados, ainda que de consumo. Na verdade, a força normativa da Constituição nessa seara específica deve ser interpretada com o objetivo de articular o princípio da autonomia da vontade com a dignidade da pessoa humana, assegurando direitos mínimos ao consumidor em superendividamento, bem como para frear o avanço desmedido dos credores. O mínimo existencial enquanto faceta da dignidade da pessoa humana se revela:

[...] como todo o conjunto de prestações materiais indispensáveis para assegurar a cada pessoa uma vida condigna (portanto, saudável) tem sido identificado - por muitos - como constituindo o núcleo essencial dos direitos fundamentais sociais, núcleo este blindado contra toda e qualquer intervenção por parte do Estado e da sociedade ${ }^{18}$.

\footnotetext{
16 SARLET, Ingo. A eficácia dos direitos fundamentais. $2^{\text {a }}$ ed. Porto Alegre: Livraria do Advogado, 2001, p. 343.

17 REVERBEL, Carlos Eduardo Dieder. Drittwirkung e ADI dos bancos: a proteção fundamental do consumidor ao não superendividamento. Revista de Direito do Consumidor, São Paulo, a. 26, v. 110, p. 17-57, mar./abr., 2017, p. 26-27.

18 SARLET, Ingo. Direitos fundamentais sociais, mínimo existencial e direito privado. Revista de Direito do Consumidor, São Paulo, n. 61, jan./mar., p. 90-125, 2007, p. 90.
} 
Assim, por expressar um conteúdo mínimo de dignidade - consistente em um conjunto indispensável de prestações materiais para assegurar uma vida condigna - o mínimo vital merece um tratamento específico em situações em que ele próprio é colocado em xeque. Contudo, embora presente a tutela do consumidor em âmbito constitucional, o direito brasileiro não dispõe de efetivos instrumentos jurídicos que possibilitem a proteção efetiva dos superendividados, o que vem comprometendo a garantia de acesso à justiça lapidada no art. $5^{\circ}$, inciso XXXV da Constituição Federal. Essas lacunas serão abordadas a seguir. Ao mesmo tempo, é importante destacar que elas não têm impedido os Tribunais pátrios de se pronunciarem a respeito do tema, como será discutido em maior detalhe na quarta seção.

\section{DO REGIME JURÍDICO DA INSOLVÊNCIA DO CONSUMIDOR PESSOA FÍSICA}

A legislação infraconstitucional não cuidou de regular a disciplina jurídica do superendividamento de modo específico e articulado com as suas particularidades. Alguns autores explicam que a ausência de previsão legal no Código de Defesa do Consumidor é justificada por razões históricas, uma vez que, à época em que o projeto de lei foi discutido no Congresso Nacional, o Brasil enfrentava um período de recessão econômica, em que não se cogitava a facilidade de acesso ao crédito vivenciada atualmente ${ }^{19}$.

Nesse sentido, é importante avaliar o atual panorama jurídico aplicável à disciplina da insolvência do consumidor, em destaque àquele que atinge o ápice do endividamento. Atualmente, um devedor pessoa física não empresário que alcança um passivo de dívidas suficiente a comprometer uma parcela significativa do seu patrimônio, pode se sujeitar à disciplina da insolvência civil. Oportuno ressaltar que, quanto à temática do devedor insolvente, a Lei n. 13.105/15 não conferiu tratamento inovador, se limitando a remissão às disposições da revogada Lei n. 5.869/73 enquanto não for editada uma legislação específica ${ }^{20}$.

Com efeito, no que importa à aplicabilidade do procedimento da insolvência civil ao devedor não empresário, a doutrina especializada aponta primeiramente pela necessidade de reconhecimento judicial da qualidade de devedor juridicamente insolvente. Sobre o tema, preleciona Alexandre Freitas Câmara:

\footnotetext{
19 GONÇALVES, Geyson. O superendividamento e o mínimo existencial: uma abordagem garantista. 2016. 216 f. Tese (Doutorado em Direito) - Faculdade de Direito, Universidade Federal de Santa Catarina, Florianópolis, 2016, p. 164.

20 “Art. 1.052. Até a edição de lei específica, as execuções contra devedor insolvente, em curso ou que venham a ser propostas, permanecem reguladas pelo Livro II, Título IV, da Lei n ${ }^{\circ} 5.869$, de 11 de janeiro de 1973."
} 
[p]ode-se dizer, assim, que há três requisitos para que um devedor seja, juridicamente, insolvente: em primeiro lugar, é preciso que haja um desequilíbrio patrimonial, que se verifica quando os bens do devedor são insuficientes para assegurar a satisfação de todas as suas dívidas (em outras palavras, é preciso que o passivo do devedor seja maior que seu ativo). Este é chamado requisito econômico. Há, também, um requisito pessoal, qual seja, a condição do devedor de não empresário. Por fim, há um requisito jurídico, que é a decretação judicial da insolvência. Como dito, é preciso que se pleiteie em juízo a decretação da insolvência, para que o devedor passe a ser assim tratado (do ponto de vista jurídico). A situação jurídica de insolvência, portanto, só é alcançada depois do provimento judicial que declara o devedor insolvente. Somente com a presença dos três requisitos, simultaneamente, é que se poderá iniciar a execução coletiva contra o devedor insolvente ${ }^{21}$.

Assim, partindo do que dispõe o Código Buzaid, verifica-se que a sistemática da insolvência civil é composta, em resumo, por duas fases sequenciais: a primeira é cognitiva, destinada à verificação do montante de débitos contraído pelo devedor, sob o crivo do contraditório e da ampla defesa. Verificado e declarado por sentença o estado de calamidade financeira, se segue para a fase executiva, na qual será instaurada a execução coletiva ou universal para a realização paritária dos créditos dos exequentes.

Iniciada a fase executiva, contudo, a legislação processual apresenta efeitos da sentença que, aparentemente, não se compatibilizam com as peculiaridades do consumidor insolvente. Conforme o que dispõem os artigos $751^{22}$ e $752^{23}$ do CPC de 1973, uma vez declarada a insolvência por sentença, ocorrerá o vencimento antecipado das dívidas; arrecadação de todos os bens suscetíveis de penhora, presentes e futuros; instauração da execução universal e, notadamente, a perda do direito de administração e disposição dos bens, ocasião em que o juízo processante deverá nomear um administrador judicial que ficará encarregado de promover a arrecadação do patrimônio restante, o afetando à realização do passivo.

Esses efeitos da declaração de insolvência, especialmente a perda do direito de administração, impedem o consumidor de utilizar os instrumentos jurídicos destinados à sua reinserção. Provocam, na verdade, o efeito oposto, acentuando sua exclusão social e o retirando, ainda que temporariamente, do mercado de consumo. Por outro lado, ao contrário do regramento dispensado pela Lei de Falências e Recuperação Judicial e Extrajudicial, não militam em favor do consumidor os direitos subjetivos à renegociação das dívidas, à suspensão

21 CÂMARA, Alexandre Freitas. Lições de Direito Processual Civil. v. 2. $23^{\mathrm{a}}$ ed. São Paulo: Atlas, 2014 , p. 371. 22 “Art. 751. A declaração de insolvência do devedor produz: I - o vencimento antecipado das suas dívidas; II - a arrecadação de todos os seus bens suscetíveis de penhora, quer os atuais, quer os adquiridos no curso do processo; III - a execução por concurso universal dos seus credores."

23 “Art. 752. Declarada a insolvência, o devedor perde o direito de administrar os seus bens e de dispor deles, até a liquidação total da massa." 
das cobranças, à dilatação dos prazos de vencimento dos pagamentos ou mesmo à flexibilização das obrigações. Assim, a tutela do superendividado pessoa física parece ir na contramão do direito fundamental previsto no artigo $5^{\circ}$, inciso XXXII da Constituição Federal, uma vez que, de forma contraditória, o ordenamento jurídico prevê disciplina de soerguimento mais favorável à atividade empresarial do que ao consumidor que é, em última análise, destinatário da proteção constitucional da pessoa humana.

Não por acaso, alguns autores criticam a incidência do regramento da insolvência civil ao consumidor superendividado atribuindo a esse tratamento jurídico a alcunha de "morte civil", justamente por retirar a completa autonomia da pessoa física tutelada. Nesse sentido, preleciona Daniel Bucar:

[o] abismo que separa o concurso universal da sociedade empresária e da pessoa humana reside no fato de que o patrimônio investido na atividade empresária é instrumento material para o exercício de seu objeto social, cujo cumprimento pode ser - e inclusive o é em via de regra - interrompido. Cessar irrestritamente a atividade econômica da pessoa, retirando-lhe provisão material necessária para seus projetos sobretudo - existenciais, é conduzi-la para além da redução de autonomia almejada: trata-se, se não de uma morte civil, de uma deliberada utilização do procedimento para aparelhagem penal ${ }^{24}$.

Em vista das previsões destinadas à execução do devedor insolvente, ainda resta ao consumidor a possibilidade de utilização de instrumentos processuais alternativos para assegurar os seus interesses, como as ações revisionais de cláusulas contratuais. A fundamentação legal que sustenta essa possibilidade se escora no disposto no art. $6^{\circ}$, inciso V do $\mathrm{CDC}^{25}$, conjugado com o art. 51, caput e inciso IV, também do $\mathrm{CDC}^{26}$, os quais garantem o direito à revisão contratual nas hipóteses de cláusulas abusivas, lesão e desnivelamento da base do negócio jurídico. Sob o vértice processual, a possibilidade de rediscutir as condições contratuais também decorre da autorização genérica prevista no art. 19, inciso I do CPC $^{27}$, que assegura ao autor o direito de provocar a jurisdição com o objetivo de ver declarado pelo Poder Judiciário o modo de ser da relação jurídica.

\footnotetext{
24 BUCAR, Daniel. Superendividamento: reabilitação patrimonial da pessoa humana. São Paulo: Saraiva, 2017 , p. 85 .

25 “Art. $6^{\circ}$ São direitos básicos do consumidor: [...] V - a modificação das cláusulas contratuais que estabeleçam prestações desproporcionais ou sua revisão em razão de fatos supervenientes que as tornem excessivamente onerosas."

26 “Art. 51. São nulas de pleno direito, entre outras, as cláusulas contratuais relativas ao fornecimento de produtos e serviços que: [...] IV - estabeleçam obrigações consideradas iníquas, abusivas, que coloquem o consumidor em desvantagem exagerada, ou sejam incompatíveis com a boa-fé ou a equidade."

27 “Art. 19. O interesse do autor pode limitar-se à declaração: I - da existência, da inexistência ou do modo de ser de uma relação jurídica."
} 
Essas disposições legais de direito material se assentam no que a doutrina denomina de onerosidade excessiva da obrigação, instituto semelhante ao tratado no art. 478 do Código $\mathrm{Civil}^{28}$, mas que com esse não se confunde. Apesar da distinção ontológica, o fundamento maior do postulado, tanto no Direito do Consumidor quanto no Direito Civil, repousa na cláusulageral rebus sic stantibus, assim como na necessidade de mitigação do princípio da pacta sunt servanda frente a situações inesperadas, imprevisíveis, não primariamente conjecturada pelas partes contratantes, de modo a permitir a repactuação com o fim de preservar, ou mesmo resolver, a avença afetada pelo desequilíbrio obrigacional. Ao articular os princípios da teoria geral dos contratos à luz da teoria da revisão contratual pela onerosidade excessiva, Carlos Roberto Gonçalves explica:

\begin{abstract}
[e]mbora o princípio da pacta sunt servanda ou da intangibilidade do contrato seja fundamental para a segurança nos negócios é fundamental a qualquer organização social, os negócios jurídicos podem sofrer as consequências de modificações posteriores das circunstâncias, com quebra insuportável da equivalência. Tal constatação deu origem ao princípio da revisão dos contratos ou da onerosidade excessiva, que se opõe àquele, pois permite aos contratantes recorrerem ao Judiciário, para obterem alteração da convenção e condições mais humanas, em determinadas situações $^{29}$.
\end{abstract}

Nessa linha de pensamento e à luz do Direito do Consumidor, a onerosidade excessiva apresenta uma diferença significativa com relação ao instituto previsto no Código Civil. Enquanto o artigo 478 do Código de Miguel Reale exige a demonstração da imprevisibilidade da prestação que tornou desproporcional o contrato, o CDC mitiga o postulado, condicionando a aplicação da teoria apenas à demonstração da circunstância superveniente que desequilibrou a base objetiva do negócio jurídico. Ou seja, para o consumidor é dispensada a demonstração da circunstância imprevisível, bastando que ela seja superveniente e suficiente a desnivelar a proporcionalidade do contrato de consumo.

Com efeito, Claudia Lima Marques ressalta a distinção estabelecida entre o diploma consumerista e o Código Civil, sobrelevando o avanço do Código de Defesa do Consumidor na temática. Para a autora:

[a] norma do art. $6^{\circ}$ do $\mathrm{CDC}$ avança ao não exigir que o fato superveniente seja imprevisível ou irresistível, apenas exige a quebra da base objetiva do negócio, a

\footnotetext{
28 “Art. 478. Nos contratos de execução continuada ou diferida, se a prestação de uma das partes se tornar excessivamente onerosa, com extrema vantagem para a outra, em virtude de acontecimentos extraordinários e imprevisíveis, poderá o devedor pedir a resolução do contrato. Os efeitos da sentença que a decretar retroagirão à data da citação."

29 GONÇALVES, Carlos Roberto. Direito Civil Brasileiro: Contratos e Atos Unilaterais. São Paulo: Saraiva, 2014, p. 192.
} 
quebra de seu equilíbrio intrínseco, a destruição da relação de equivalência entre prestações, ao desaparecimento do fim essencial do contrato. Em outras palavras, o elemento autorizador da ação modificadora do Judiciário é o resultado objetivo da engenharia contratual, que agora apresenta a mencionada onerosidade excessiva para o consumidor, resultado de simples fato superveniente, fato que não necessita ser extraordinário, irresistível, fato que podia ser previsto e não foi ${ }^{30}$.

A par das disposições concernentes à execução do devedor insolvente, o ordenamento jurídico possibilita a propositura de ações judiciais pelo consumidor superendividado, com o objetivo de provocar a jurisdição a sanar a lacuna deixada pelo legislador na hipótese de superendividamento com arrimo nas disposições já existentes no Código de Defesa do Consumidor, concatenadas com os direitos e garantia fundamentais assegurados na Constituição Federal.

Nesse sentido, a lacuna legislativa não impediu a judicialização do tema, o que tem levado diversos Tribunais brasileiros a se pronunciarem sobre o superendividamento. Destacase que o enfrentamento da problemática é imposto não só pelo imperativo constitucional da inafastabilidade da jurisdição (art. $5^{\circ}$, inciso XXXV da $\mathrm{CF}^{31}$ ), mas por também haver previsão expressa no Código de Processo Civil (CPC, art. 140 32) e na Lei de Introdução às Normas do Direito Brasileiro (art. $4^{033}$ ) da vedação ao non liquet, consistente no dever do Estado-juiz se pronunciar a respeito das matérias colocadas à sua apreciação. No entanto, ainda que pertinente a tese da onerosidade excessiva ante a ausência de regramento legal específico, pairam sobre o tema manifestações divergentes na jurisprudência, que ora acolhem a tese do consumidor ou ora se inclinam em favor dos argumentos dos credores.

\section{SUPERENDIVIDAMENTO DO CONSUMIDOR E JURISPRUDÊNCIA}

A jurisprudência do Superior Tribunal de Justiça (STJ), a exemplo do precedente fixado no julgamento do Recurso Especial n. 1.584.501/SP, já reconheceu a onerosidade excessiva e autorizou o reestabelecimento do equilíbrio contratual por meio da diminuição do percentual

\footnotetext{
30 MARQUES, Claudia Lima. Contratos no Código de Defesa do Consumidor: O novo regime das relações contratuais. $3^{\text {a }}$ ed. São Paulo: Editora Revista dos Tribunais, 1999, p. 413.

31 “Art. $5^{\circ}$ Todos são iguais perante a lei, sem distinção de qualquer natureza, garantindo-se aos brasileiros e aos estrangeiros residentes no País a inviolabilidade do direito à vida, à liberdade, à igualdade, à segurança e à propriedade, nos termos seguintes: [...] XXXV - a lei não excluirá da apreciação do Poder Judiciário lesão ou ameaça a direito."

32 “Art. 140. O juiz não se exime de decidir sob a alegação de lacuna ou obscuridade do ordenamento jurídico."

33 "Art. 4o Quando a lei for omissa, o juiz decidirá o caso de acordo com a analogia, os costumes e os princípios gerais de direito."
} 
de desconto em conta corrente do consumidor contratante, fundada na tese do superendividamento. No caso concreto, o Banco Santander S/A, inconformado com o acórdão do Tribunal de Justiça do Estado de São Paulo (TJSP), recorreu ao tribunal de superposição, alegando a legalidade dos descontos efetuados na conta corrente nos moldes do que havia sido pactuado originariamente no contrato, assim como o descabimento da redução do percentual com base na renda líquida do contratante.

Segundo o que constou no acórdão, os descontos realizados pela instituição financeira decorriam de uma confissão e renegociação de dívida no valor de $\mathrm{R} \$ 122.209,21$, na modalidade de empréstimo consignado, a ser quitado mediante o desconto de 72 parcelas mensais no valor de $\mathrm{R} \$ 1.697,35$. Contudo, os descontos incidiam diretamente sobre os proventos do correntista, sendo que a renda líquida mensal perfazia o valor de $\mathrm{R} \$ 1.673,91$, resultando na restrição de quase cem por cento da totalidade da sua renda.

Ao analisar o mérito do recurso, a Terceira Turma do STJ rejeitou os argumentos da instituição credora e, partindo do que preveem as disposições constitucionais, manteve integralmente o acórdão recorrido, estabelecendo como limite de desconto o percentual de $30 \%$. Segundo o relator, Ministro Paulo de Tarso Sanseverino, o montante descontado mensalmente pela recorrente implicava na supressão de quase totalidade dos proventos do mutuante, o que permitia identificar no caso concreto a ofensa ao princípio da dignidade da pessoa humana. $\mathrm{O}$ relator ainda destacou que a ausência de previsão legal específica à temática do consumidor superendividado não era argumento capaz de impedir o Poder Judiciário de restabelecer o equilíbrio contratual, ainda mais quando é possível verificar que a relação privada implicava em comprometimento acentuado da subsistência digna do contratante e do seu respectivo núcleo familiar. Nesse sentido, assim pronunciou o ministro:

[e]nquanto não há legislação específica acerca do tema, as soluções para o superendividamento dos consumidores têm sido buscadas na via jurisprudencial.

De todo modo, constitui dever do Poder Judiciário o controle desses contratos de empréstimo para evitar que abusos possam ser praticados pelas instituições financeiras interessadas, especialmente nos casos de crédito consignado. Não se desconhece que esses contratos financeiros foram celebrados com a anuência do consumidor, no exercício dos poderes outorgados pela liberdade contratual.

Entretanto, o princípio da autonomia privada longe está de ser absoluto em nosso sistema jurídico. [...]

Com efeito, se o desconto consumir parte excessiva dos vencimentos do consumidor, colocará em risco a sua subsistência e de sua família, ferindo o princípio da dignidade da pessoa humana. No caso dos autos, esse risco é evidente, pois os descontos alcançam quase $100 \%$ dos proventos da consumidora demandante. Cabível, portanto, estabelecer um limite para esses descontos. Nesse passo, a jurisprudência desta Corte Superior tem entendido que os descontos em conta-corrente utilizada para 
o recebimento de salário devem ser limitados a 30\% (trinta por cento) dos vencimentos do correntista, excluídos os descontos obrigatórios. [...]

Verifica-se, portanto, que o Tribunal de origem decidiu em sintonia com o entendimento desta Corte Superior, quanto ao limite dos descontos em conta-corrente, ficando limitados a 30\% da remuneração líquida do devedor após os descontos obrigatórios. De outra parte, relativamente à insurgência contra as astreintes, o banco recorrente não apontou o dispositivo de lei federal que fundamenta a interposição do recurso especial, o que atrai a incidência do óbice da Súmula 284/STF. Destarte, o recurso especial não merece ser provido. Ante o exposto, voto no sentido de negar provimento ao recurso ${ }^{34}$.

É certo que o julgamento em destaque não se enquadra nos precedentes de observância obrigatória, porquanto o caso concreto não se amoldava às hipóteses previstas no art. 927 do $\mathrm{CPC}^{35}$. Todavia, o precedente tem encontrado franca adesão na jurisprudência dos tribunais de alçada, a exemplo do Tribunal de Justiça do Estado de Goiás, que acolheu raciocínio semelhante nos autos do Agravo de Instrumento n. 5467776-74.2019.8.09.0000, julgado pela Quinta Câmara Cível.

No julgamento do aludido recurso, os desembargadores acolheram expressamente a tese da onerosidade excessiva como hipótese de revisão contratual ante a constatação do quadro de superendividamento do consumidor. O resultado do recurso culminou na reforma da decisão interlocutória de primeira instância que havia indeferido a tutela provisória de urgência e a consequente redução do montante do desconto efetivado na conta corrente do consumidor, ora agravante, ao patamar de $30 \%$ sobre a renda, em sintonia com precedente fixado no REsp n. 1.584.501/SP. O acórdão do tribunal goiano foi assim ementado:

AGRAVO DE INSTRUMENTO. AÇÃO DE OBRIGAÇÃO DE FAZER C/C PEDIDO DE INDENIZAÇÃO POR DANOS MORAIS E MATERIAIS C/C PEDIDO DE TUTELA ANTECIPADA. EMPRÉSTIMO PESSOAL COM DESCONTO EM CONTA-CORRENTE TAMBÉM UTILIZADA PARA RECEBER SALÁRIO. ANTECIPAÇÃO DA TUTELA PARA A SUSPENSÃO DOS DESCONTOS DA PARTE QUE ULTRAPASSAR A LIMITAÇÃO DE $30 \%$ (TRINTA POR CENTO) DA REMUNERAÇÃO LÍQUIDA. POSSIBILIDADE. SUPERENDIVIDAMENTO. PRESERVAÇÃO DO MÍNIMO EXISTENCIAL. DIGNIDADE DA PESSOA HUMANA. DECISÃO AGRAVADA REFORMADA. 1. O deferimento de tutela de urgência apenas será concedida se observados, concomitantemente, os requisitos do artigo 300, caput, do Código de Processo Civil, quais sejam, a probabilidade do direito e o perigo de dano ou risco ao resultado útil do processo, bem como não se vislumbre a possibilidade irreversibilidade do provimento antecipado. 2. Ao Poder Judiciário compete reconhecer, em face das

\footnotetext{
${ }^{34}$ BRASIL. Superior Tribunal de Justiça. REsp 1.584.501/SP. Rel. Ministro Paulo de Tarso Sanseverino, Terceira Turma. Julgado em: 06 de outubro de 2016. DJe de 13 de outubro de 2016, p. 6-9.

35 “Art. 927. Os juízes e os tribunais observarão: I - as decisões do Supremo Tribunal Federal em controle concentrado de constitucionalidade; II - os enunciados de súmula vinculante; III - os acórdãos em incidente de assunção de competência ou de resolução de demandas repetitivas e em julgamento de recursos extraordinário e especial repetitivos; IV - os enunciados das súmulas do Supremo Tribunal Federal em matéria constitucional e do Superior Tribunal de Justiça em matéria infraconstitucional; V - a orientação do plenário ou do órgão especial aos quais estiverem vinculados."
} 
peculiaridades do caso concreto, a possibilidade de limitação dos descontos efetuados na conta bancária do consumidor, a fim de evitar abusos por parte das instituições bancárias e preservar o princípio da dignidade da pessoa humana. 3. O princípio da autonomia da vontade deve ser mitigado quando o endividamento da parte afeta a sua subsistência. 4. No caso, os descontos em conta-corrente do Autor decorrente de empréstimos bancários, ainda que na modalidade pessoal, submetem-se à limitação ao percentual de $30 \%$ (trinta por cento) dos seus rendimentos líquidos, sob pena de afronta ao princípio da dignidade da pessoa humana, bem como, de inviabilizar o seu sustento e de sua família. AGRAVO DE INSTRUMENTO CONHECIDO E PROVIDO. ${ }^{36}$

Apesar das decisões acima transcritas que são favoráveis aos consumidores, a jurisprudência ainda é vacilante, não havendo manifestação unânime no assunto, notadamente no âmbito do próprio STJ. Exemplifica a ausência de uniformidade o caso em que os ministros da Quarta Turma julgadora não conferiram ao REsp n. 1.586.910/SP a mesma solução dada nos autos do REsp n. 1.584.501/SP julgado pela Terceira Turma, mesmo se tratando de situações aparentemente semelhantes. O caso concreto que inaugurou a divergência no âmbito do STJ remonta ao julgamento do recurso especial interposto pelo Banco do Brasil S/A que resultou na reforma do acórdão proferido pelo TJSP que havia impedido a instituição financeira de efetuar descontos na conta corrente do consumidor em patamar superior a trinta por cento dos rendimentos líquidos.

A título de contextualização, a celeuma se originou a partir da celebração, pelo mutuante, de pacto contratual com a intenção de obter mútuo com juros menores que os do cheque especial, o que resultou na consignação do valor de $\mathrm{R} \$ 114.480,55$ a ser pago em oitenta e cinco parcelas mensais de $\mathrm{R} \$ 2.543,56$. Esse valor mensal, segundo o alegado pelo correntista, comprometia quase a totalidade do seu sustento, o que teria caracterizado o superendividamento.

Ao julgar o recurso interposto, o Ministro relator Luís Felipe Salomão deu razão aos argumentos da instituição financeira, sobrelevando o princípio da autonomia privada dos contratantes e a impossibilidade do dirigismo contratual. Ainda, o Ministro refutou a incidência do precedente da Terceira Turma do STJ, que inclusive havia subsidiado a prolação do acórdão recorrido, destacando a inexistência de previsão legal para a redução do porcentual do desconto e a possibilidade de solução do caso concreto por intermédio do procedimento da insolvência civil ainda regulada pelo Código de Processo Civil de 1973. Seguindo estas premissas, assim pronunciou o ministro:

\footnotetext{
36 BRASIL. Tribunal de Justiça do Estado de Goiás. Agravo de Instrumento n. 5467776-74.2019.8.09.0000. Rel. Francisco Vildon José Valente. $5^{\text {a }}$ Câmara Cível. Julgado em: 18 de novembro de 2019, DJe de 18 de novembro de 2019.
} 
[n]o Brasil, cumpre ressaltar que, à míngua de novas disposições legais específicas, há procedimento, já previsto no ordenamento jurídico, para casos de superendividamento ou sobreendividamento - do qual podem lançar mão os próprios devedores -, que é o da insolvência civil, e que, na vigência do CPC/2015, permanece disciplinada pelo Código Buzaid (vide art. 1.052 do novel Diploma). Mesmo o Projeto de lei acerca do superendividamento, como transcrito no precedente da Terceira Turma do STJ, se propõe a disciplinar "os contratos em que o modo de pagamento da dívida envolva autorização prévia do consumidor pessoa natural para consignação em folha de pagamento".

2.4. Assim considerando a questão, não parece razoável e isonômico, a par de não ter nenhum supedâneo legal, aplicar a limitação legal prevista para empréstimo consignado em folha de pagamento, de maneira arbitrária, a contrato específico de mútuo livremente pactuado. [...]

2.5. No caso, como reconhece o acórdão recorrido - que explicitamente se vale de analogia -, não há previsão legal para a medida adotada, e o ordenamento jurídico, de modo um tanto assemelhado ao modelo americano, já prevê a medida específica do instituto da insolvência civil, de que pode lançar mão o devedor, em caso de sobreendividamento. Assim também o precedente da Terceira Turma assenta que se vale da analogia para, em consonância com o princípio da dignidade humana, estender a limitação legal, referente a empréstimos em folha, para a relação contratual diversa. Contudo, penso que a analogia não pode ser invocada. Konrad Hesse observa que, ordinariamente, é o legislador democrático que está devidamente aparelhado para a apreciação das limitações necessárias à autonomia privada em face dos outros valores e direitos constitucionais. (HESSE, Konrad. Elementos de direito constitucional da República Federal da Alemanha. Trad. Luís Afonso Heck. Porto Alegre: Sérgio Antonio Fabris, 1998, p. 285) ${ }^{37}$.

O voto proferido, embora prevalecente, não foi acolhido à unanimidade pelos demais integrantes do colegiado. Em oposição ao relator, o ministro Marco Buzzi inaugurou a divergência em voto-vista, pelo qual foi acompanhado pelo ministro Raul Araújo, no sentido de manter a íntegra do acórdão proferido pelo tribunal bandeirante, reconhecendo a legitimidade da limitação do porcentual de desconto a trinta por cento dos proventos do correntista.

Dentre as premissas sustentadas no voto divergente, o ministro ponderou a compatibilização do princípio da autonomia privada com a preservação do mínimo existencial, apontando que a solução ao caso concreto deveria garantir ao consumidor condições mínimas de subsistência sem que implicasse em configuração de estado de penúria. Pela relevância do voto divergente, destacam-se as seguintes passagens:

[o]ra, não se pode apenar a inadimplência com a condenação à penúria financeira, à completa ausência do mínimo existencial para a vida, pois essa seria uma sanção absolutamente desumana, própria de Estados onde vigora a barbárie, e mais aplicada por quem não tem além de legitimidade, autoridade para tanto (instituições financeiras e a elas equiparadas), não podendo ser olvidado que entre os fundamentos da nossa

37 BRASIL. Superior Tribunal de Justiça. REsp 1.586.910/SP. Rel. Ministro Luis Felipe Salomão, Quarta Turma. Julgado em: 29 de agosto de 2017. DJe de 03 de outubro de 2017, p. 14-16. 
República sobressai o princípio da dignidade da pessoa humana, positivado no artigo $1^{\text {o }}$, inciso III, da Constituição Federal de 1988, in verbis: [...]

Para relembrar, explicita-se os objetivos fundamentais da República Federativa do Brasil dentre os quais está construir uma sociedade justa e solidária, promover o bem de todos e erradicar a pobreza e a marginalização: [...]

Sobre esse prisma, amparado no fundamento da dignidade da pessoa humana e nos objetivos fundamentais estabelecidos na Constituição Federal, a legislação brasileira assegura ao trabalhador o recebimento de salário proveniente do seu esforço, para a manutenção da sua subsistência e da sua família, considerando, inclusive, impenhorável tal verba. [...]

Munido desse espírito, mais recentemente, a jurisprudência, como forma de equacionar e harmonizar os interesses em litígio, valendo-se do princípio da razoabilidade, passou a mitigar o entendimento acerca da viabilidade de retenção salarial apenas nos moldes realizados em folha de pagamento, admitindo, mediante uma aplicação analógica e ante a prevalência do princípio da autonomia da vontade das partes, a limitação dos descontos diretamente na conta-corrente, por parte da instituição bancária, em até $30 \%$ (trinta por cento) dos proventos do devedor, o que evita a completa expropriação do salário pelo banco, bem ainda, permite a subsistência da autonomia da vontade das partes, porém não de forma absoluta, pois o próprio Código Civil de 2002, em seu art. 421, estabelece textualmente que "a liberdade de contratar será exercida em razão e nos limites da função social do contrato".

Desta forma, o princípio da autonomia privada deve se coadunar com outros fundamentos do sistema jurídico, tais como função social do contrato, boa-fé objetiva, dignidade da pessoa humana, esse último, inclusive, positivado no art. $1^{\circ}$, III, da Constituição Federal, esta que, como já referido, tem por objetivos erradicar a pobreza e a marginalização e promover o bem de todos $[\ldots]^{38}$.

A partir da análise dos precedentes do STJ, é possível observar que o tema do superendividamento ainda não recebeu tratamento uniforme pela jurisprudência, especialmente ante a ausência de disciplina específica para a matéria. Assim, o enfrentamento do tema tem se baseado na invocação de princípios e no emprego de analogia, o que evidencia que a lacuna legislativa instala uma situação de insegurança jurídica, comprometendo a efetividade da garantia constitucional de acesso à justiça.

\section{ACESSO À JUSTIÇA E A UTILIZAÇÃO DE MÉTODOS ALTERNATIVOS DE SOLUÇÃO DE CONFLITOS}

Conforme já observado, o superendividamento ainda é um problema carente de solução específica no direito brasileiro. Embora haja previsão constitucional dispensando ao consumidor especial proteção pelo Estado, não há disposições legais específicas sobre a temática, além de haver séria divergência jurisprudencial. Ao articular a omissão legislativa e a oscilação jurisprudencial, é possível notar que o superendividamento no Brasil é permeado

\footnotetext{
${ }^{38}$ BRASIL. Superior Tribunal de Justiça. REsp 1.586.910/SP. Rel. Ministro Luis Felipe Salomão, Quarta Turma. Julgado em: 29 de agosto de 2017. DJe de 03 de outubro de 2017, p. 3-10.
} 
pela insegurança jurídica, dada a ausência de uma mínima previsibilidade dos direitos do consumidor. Quando muito, busca-se o emprego de analogias e métodos de integração legislativa que nem sempre tem a força de garantir a preservação do mínimo existencial, levando ao comprometimento de direitos individuais.

No que diz respeito à segurança jurídica, Ingo W. Sarlet explana que o pensamento constitucional contemporâneo tende a identificá-la como direito fundamental, estruturante do Estado de Direito. Assim, o cenário legislativo ou jurisprudencial que coloca em risco a segurança das relações jurídicas tende a transformar o governo das leis em despotismo, abrindo margem ao retrocesso em matéria de direitos fundamentais. Nas palavras do autor:

[c]erto é que havendo, ou não, menção expressa a um direito à segurança jurídica, de há muito, pelo menos no âmbito do pensamento constitucional contemporâneo, se enraizou a ideia de que um autêntico Estado de Direito é sempre também - pelo menos em princípio e num certo sentido - um Estado da segurança jurídica, já que, do contrário, também o 'governo das leis' (até pelo fato de serem expressão da vontade política de um grupo) poderá resultar em despotismo e toda a sorte de iniquidades. Com efeito, a doutrina constitucional contemporânea, de há muito e sem maior controvérsia no que diz com este ponto, tem considerado a insegurança jurídica como expressão inarredável do Estado de Direito, de tal sorte que a segurança jurídica passou a ter o status de subprincípio concretizador princípio fundamental e estruturante do Estado de Direito. Assim, para além de assumir a condição de direito fundamental da pessoa humana, a segurança jurídica constitui simultaneamente princípio fundamental da ordem jurídica estatal e, para além desta, da própria ordem jurídica internacional ${ }^{39}$.

Diante desta problemática e ante a insegurança instalada nas relações de consumo, cabe analisar o tema à luz do Direito Constitucional de acesso à justiça, expressamente previsto no artigo $5^{\circ}$, inciso XXXV da Constituição Republicana. Segundo a sua redação literal, o direito fundamental à inafastabilidade da jurisdição se traduz na impossibilidade da lei excluir do Poder Judiciário o poder-dever de apreciar qualquer lesão ou ameaça a direito.

Interessante notar que a referida previsão constitucional não só impede que a lesão ao direito não seja excluída da apreciação judicial, como também se apresenta como uma garantia instrumental, na medida em que impõe a viabilização de meios hábeis a permitir o acesso à ordem jurídica justa. Com efeito, a ausência ou ineficiência de instrumentos que levem o jurisdicionado à tutela dos seus direitos compromete em maior grau a observância das liberdades individuais, tornando as legislações meras proclamações de direitos. Nessa linha de

\footnotetext{
39 SARLET, Ingo. A Eficácia do Direito Fundamental à Segurança Jurídica: dignidade da pessoa humana, direitos fundamentais e proibição de retrocesso social no Direito Constitucional Brasileiro. Revista Eletrônica sobre a Reforma do Estado (RERE), Salvador, Instituto Brasileiro de Direito Púbico, n. 21, p. 1-39, mar./maio, 2010. Disponível em: http://www.direitodoestado.com.br/rere/edicao/21. Acesso em: 29 mar. 2021.
} 
pensamento, Mauro Cappelletti e Bryan Garth asseveram, ao discorrer sobre o direito de acesso à justiça:

[d]e fato, o direito ao acesso efetivo tem sido progressivamente reconhecido como sendo de importância capital entre os novos direitos individuais e sociais, uma vez que a titularidade de direitos é destituída de sentido, na ausência de mecanismos para sua efetiva reivindicação. $\mathrm{O}$ acesso à justiça pode, portanto, ser encarado como requisito fundamental - o mais básico dos direitos humanos - de um sistema jurídico moderno e igualitário que pretenda garantir, e não apenas proclamar os direitos de $\operatorname{todos}^{40}$.

Analisando a questão do superendividamento à luz do direito fundamental em destaque e considerando o atual panorama legislativo, é possível depreender que, nessa hipótese específica, a preservação do mínimo existencial é melhor tutelada por meio de providências alternativas, anteriores à atuação definitiva da jurisdição. O emprego de técnicas desta índole, em especial as mediações e conciliações, pode viabilizar com maior efetividade e celeridade o acesso à ordem jurídica justa, assim dando maior cumprimento às disposições constitucionais, além de evitar a judicialização excessiva da matéria.

Ao analisar a solução de contendas sob o ângulo do direito de acesso à justiça, Kazuo Watanabe esclarece que a Constituição não se referiu, hermeticamente, ao acesso ao Poder Judiciário. Nas palavras do autor, “[...] a problemática do acesso à Justiça não pode ser estudada nos acanhados limites do acesso aos órgãos judiciais já existentes. Não se trata apenas de possibilitar o acesso à Justiça enquanto instituição estatal, e sim de viabilizar o acesso à ordem jurídica justa"41.

Nesse contexto, o estímulo às práticas conciliatórias possibilitaria que os sujeitos da relação de consumo avençassem uma melhor solução ao impasse contratual gerado pelo superendividamento dentro do espectro de liberalidade conferido pelos contratos, balizados pela autonomia da vontade e pela função social do contrato. Essa alternativa não só impediria que o consumidor se tornasse alvo de um procedimento judicial de declaração de insolvência, como também mitigaria a insegurança jurídica estabelecida pelas divergências entre os precedentes.

Quanto à adoção de práticas dessa envergadura, há um relevante estudo realizado pelas magistradas do Tribunal de Justiça do Estado do Rio Grande do Sul (TJRS), Káren Rick

\footnotetext{
40 CAPELETTI, Mauro; GARTH, Bryan. Acesso à justiça. Tradução de Ellen Gracie Northfleet. Porto Alegre: Fabris, 1998, p. 111-112.

41 WATANABE, Kazuo. Acesso à justiça e sociedade moderna. In: GRINOVER, Ada Pellegrini et al. Participação e processo. São Paulo: Revista dos Tribunais, 1998, p. 128-135, p. 128.
} 
Danilevicz Bertoncello e Clarissa Costa de Lima, cujo objeto consistia em um projeto-piloto objetivando a reinserção social do consumidor superendividado por meio da conciliação paraprocessual ou processual, obtida em audiências de renegociação amigável. As audiências eram presididas pelas juízas, que propunham a renegociação com cada credor na mesma solenidade, levando em consideração as condições pessoais do superendividado e respeitando a preservação de seu mínimo vital ${ }^{42}$.

Dentre as propostas apresentadas na ocasião das renegociações, havia a possibilidade de parcelamento das dívidas, concessão de moratória com alteração no vencimento da obrigação, redução dos encargos ou, até mesmo, perdão parcial ou total da dívida. Em caso de anuência das partes, o juízo homologava o acordo, transformando-o em título executivo judicial, cujo eventual descumprimento autorizaria a sua execução perante o foro do domicílio do consumidor, nos moldes do art. 101, inciso I do $\mathrm{CDC}^{43}$.

Relata o estudo protagonizado pelas magistradas que o elevado índice de adesão à conciliação levou os próprios credores a auxiliarem o Poder Judiciário gaúcho a divulgar a iniciativa, tendo em vista a efetividade da medida para salvaguarda dos interesses de ambos os contratantes. Por certo, o sucesso das práticas conciliatórias possibilitou com maior profundidade o acesso à ordem jurídica justa sem que houvesse necessidade de dirigismo contratual por parte do Poder Judiciário.

Seguindo ideia semelhante à apresentada no projeto-piloto do TJRS, o Tribunal de Justiça do Distrito Federal e Territórios (TJDFT) instalou, por meio da Portaria n. 49 de 16 de dezembro de 2014 do Gabinete da Presidência do Tribunal ${ }^{44}$, o Programa de Prevenção e Tratamento de Consumidores Superendividados, no âmbito dos Centros Judiciários de Solução de Conflitos e Cidadania (CEJUSCs), vinculados ao Núcleo Permanente de Mediação e Conciliação (NUPEMEC).

\footnotetext{
42 BERTONCELLO, Káren Rick Danilevicz; COSTA DE LIMA, Clarissa. Adesão ao projeto conciliar é legal CNJ projeto-piloto: tratamento das situações de superendividamento do consumidor. [S. l.], [S. d.]. Disponível em: https://www1.tjrs.jus.br/export/processos/conciliacao/doc/projeto_superendividamento.pdf. Acesso em: 29 mar. 2021.

43 "Art. 101. Na ação de responsabilidade civil do fornecedor de produtos e serviços, sem prejuízo do disposto nos Capítulos I e II deste título, serão observadas as seguintes normas: I - a ação pode ser proposta no domicílio do autor."

${ }^{44}$ DISTRITO FEDERAL. Tribunal de Justiça do Distrito Federal e dos Territórios. Portaria 49, de 16 de dezembro de 2014. Institui o Programa de Prevenção e Tratamento de Consumidores Superendividados SUPERENDIVIDADOS, no âmbito dos Centros Judiciários de Solução de Conflitos e Cidadania - CEJUSCs, vinculados ao Núcleo Permanente de Mediação e Conciliação - NUPEMEC. Brasília, DF: Gabinete da Segunda Vice-Presidência, 22 dez. 2014. Disponível em: https://www.tjdft.jus.br/publicacoes/publicacoesoficiais/portarias-gsvp/2014/portaria-gsvp-48-17-12-2014. Acesso em: 29 mar. 2021.
} 
Por meio desse programa, os CEJUSCs do Tribunal de Justiça têm um núcleo temático destinado ao superendividamento, contando com a ajuda de servidores e voluntários em atuação multidisciplinar, oferecendo apoio judicial, psicossocial e educacional. Conforme o artigo $2^{\circ}$ do ato normativo citado, a atuação desses CEJUSCs especializados é permitida quando identificado que o consumidor é uma:

[...] pessoa física, maior, capaz, de boa-fé, impossibilitada economicamente de pagar o conjunto de suas dívidas de consumo, exigíveis e vincendas, contraídas por má administração do orçamento familiar ou por acidentes da vida, como, por exemplo, morte, doença, desemprego, divórcio etc., sem o prejuízo do seu sustento e de sua família ${ }^{45}$.

Ainda, ressalva a possibilidade de atendimento daquele que se "[...] endividou em virtude de dívidas alimentícias, fiscais, habitacionais e profissionais, decorrentes de indenização ou que tenham como credora empresa pública da União Federal, dos estados e do Distrito Federal"46.

Por outro lado, de maneira inovadora, o Tribunal de Justiça prevê que a atuação desses centros especializados se dá a partir de três frentes: prevenção, tratamento e a resolução amigável de conflitos. Há uma grande preocupação dessa iniciativa com tratamento preventivo por meio da orientação do consumidor a respeito da aquisição de créditos e noções sobre educação financeira, havendo inclusive convênios com universidades e com o próprio Banco Central para o cumprimento deste objetivo.

Segundo dados do próprio Tribunal, há um índice de $97 \%$ de satisfação dos consumidores que participaram da iniciativa. Além disso, desde a sua criação, as ações

\footnotetext{
45 "Art. $2^{\circ}$ Considera-se consumidor superendividado apto a participar do Programa SUPERENDIVIDADOS a pessoa física, maior, capaz, de boa-fé, impossibilitada economicamente de pagar o conjunto de suas dívidas de consumo, exigíveis e vincendas, contraídas por má administração do orçamento familiar ou por acidentes da vida, como, por exemplo, morte, doença, desemprego, divórcio etc., sem o prejuízo do seu sustento e de sua família. Parágrafo único. Estão excluídas do Programa SUPERENDIVIDADOS as dívidas alimentícias, fiscais, habitacionais e profissionais, decorrentes de indenização ou que tenham como credora empresa pública da União Federal, dos estados e do Distrito Federal" (DISTRITO FEDERAL. Tribunal de Justiça do Distrito Federal e dos Territórios. Portaria 49, de 16 de dezembro de 2014. Institui o Programa de Prevenção e Tratamento de Consumidores Superendividados - SUPERENDIVIDADOS, no âmbito dos Centros Judiciários de Solução de Conflitos e Cidadania - CEJUSCs, vinculados ao Núcleo Permanente de Mediação e Conciliação - NUPEMEC. Brasília, DF: Gabinete da Segunda Vice-Presidência, 22 dez. 2014. Disponível em: https://www.tjdft.jus.br/publicacoes/publicacoes-oficiais/portarias-gsvp/2014/portaria-gsvp-48-17-12-2014. Acesso em: 29 mar. 2021).

${ }^{46}$ DISTRITO FEDERAL. Tribunal de Justiça do Distrito Federal e dos Territórios. Portaria 49, de 16 de dezembro de 2014. Institui o Programa de Prevenção e Tratamento de Consumidores Superendividados SUPERENDIVIDADOS, no âmbito dos Centros Judiciários de Solução de Conflitos e Cidadania - CEJUSCs, vinculados ao Núcleo Permanente de Mediação e Conciliação - NUPEMEC. Brasília, DF: Gabinete da Segunda Vice-Presidência, 22 dez. 2014. Disponível em: https://www.tjdft.jus.br/publicacoes/publicacoesoficiais/portarias-gsvp/2014/portaria-gsvp-48-17-12-2014. Acesso em: 29 mar. 2021.
} 
preventivas de educação financeira já alcançaram mais de 3.200 cidadãos, havendo registro que o Centro realizou mais de 4.041 ações de tratamento entre orientações financeiras e psicossociais, entrevistas, oficinas, constelações familiares e grupos temáticos. Até o final de 2018, foram realizadas 1.706 audiências de conciliação, das quais $48 \%$ resultaram em acordos.

\section{PROJETO DE LEI N. 3515 DE 2015 DO SENADO FEDERAL: OUTRAS PERSPECTIVAS}

O êxito flagrado pelas iniciativas adotadas pelo TJRS e pelo TJDFT, evidenciam que a informação e a autonomia da vontade, expressadas no incentivo às práticas conciliatórias e de prevenção, são um caminho efetivo ao enfrentamento do superendividamento. Todavia, é certo que o alcance da segurança jurídica e, consequentemente, do acesso à ordem jurídica justa nessa seara, impõe a aprovação de reformas legislativas que atualizem o ordenamento jurídico em conformidade com a atual dinâmica do mercado de consumo, contemplando assim, uma tutela jurídica específica destinada a esse perfil de consumidor.

Estas ponderações, concatenadas com o quadro de insegurança jurídica experimentado na jurisprudência dos tribunais, reforçam a necessidade de aprovação do PL n. 3.515 de 2015 em tramitação no Congresso Nacional, o qual pretende alterar o Código de Defesa do Consumidor e o artigo 96 da Lei n. 10.741/03 (Estatuto do Idoso), para aperfeiçoar a disciplina do crédito ao consumo e dispor sobre a prevenção e o tratamento do superendividamento.

Dentre as alterações previstas no anteprojeto, se destaca a inclusão no CDC da definição legal de consumidor superendividado. Nos termos do novo artigo 54-A, §1 a, "Entende-se por superendividamento a impossibilidade manifesta de o consumidor, pessoa natural, de boa-fé, pagar a totalidade de suas dívidas de consumo, exigíveis e vincendas, sem comprometer seu mínimo existencial, nos termos da regulamentação”. Ressalta-se que o projeto de lei acompanha a doutrina majoritária e exclui da definição o devedor pessoa física que contraiu dívidas de máfé, com intuito fraudulento ou dolosamente ${ }^{47}$.

Também, o artigo $1^{\circ}$ inova ao acrescentar ao artigo $5^{\circ}$ do CDC o inciso $\mathrm{VI}^{48}$, consistente na instituição de mecanismos de prevenção e tratamento extrajudicial e judicial do

\footnotetext{
47 “Art. 54-A, $\$ 3^{\circ}$ Não se aplica o disposto neste Capítulo ao consumidor cujas dívidas tenham sido contraídas mediante fraude ou má-fé ou sejam oriundas de contratos celebrados dolosamente com o propósito de não realizar o pagamento."

48 "VI - instituição de mecanismos de prevenção e tratamento extrajudicial e judicial do superendividamento e de proteção do consumidor pessoa natural."
} 
superendividamento e de proteção do consumidor pessoa física. Esta disposição, por certo, põe em evidência a autonomia da vontade, permitindo em maior grau que os próprios contratantes encontrem a solução capaz de harmonizar as suas pretensões conforme as particularidades do negócio, reservando ao Poder Judiciário somente a interferência nos casos de manifesto abuso do direito, nos quais deve atuar para fazer valer a imperatividade das normas de proteção ao consumidor (artigo $1^{\circ}$ do CDC).

Quanto à preservação do mínimo existencial, a proposta legislativa traz disciplina específica, incorporando ao ordenamento jurídico uma preocupação expressa com a preservação dos direitos básicos do consumidor e com a eficácia horizontal dos direitos constitucionais. Assim, o artigo $1^{049}$ acrescenta ao rol dos direitos básicos (artigo $6^{\circ}$ do CDC) a garantia de práticas de crédito responsável, de educação financeira e de prevenção e tratamento de situações de superendividamento, inclusive por meio da revisão e repactuação da dívida.

No que interessa à disciplina da insolvência, o anteprojeto supre, em matéria consumerista - ainda que não totalmente - a exigência deixada pelo artigo 1.052 do CPC, passando a dispor de mecanismos específicos destinados ao consumidor insolvente. Nesse panorama, o artigo 54-E não só objetiva colocar fim à celeuma jurisprudencial atinente à legalidade da limitação dos descontos efetuados nos contratos que envolvem consignação em folha de pagamento ao patamar de $30 \%$, como também prevê solução mais efetiva do que a execução do devedor insolvente prevista no CPC de 1973, a exemplo da possibilidade do Poder Judiciário ser instado a dilatar o prazo de pagamento previsto no contrato, podendo readequálo; reduzir os encargos da dívida e a remuneração do fornecedor; assim como a constituição, consolidação ou substituição de garantias. Nesses termos, o verbete em comento disciplina:

\begin{abstract}
Art. 54-E. Nos contratos em que o modo de pagamento da dívida envolva autorização prévia do consumidor pessoa natural para consignação em folha de pagamento, a soma das parcelas reservadas para pagamento de dívidas não poderá ser superior a $30 \%$ (trinta por cento) de sua remuneração mensal líquida. § $1^{\circ} \mathrm{O}$ descumprimento do disposto neste artigo dá causa imediata à revisão do contrato ou à sua renegociação, hipótese em que o juiz poderá adotar, entre outras, de forma cumulada ou alternada, as seguintes medidas: I - dilação do prazo de pagamento previsto no contrato original, de modo a adequá-lo ao disposto no caput deste artigo, sem acréscimo nas obrigações do consumidor; II - redução dos encargos da dívida e da remuneração do fornecedor; III - constituição, consolidação ou substituição de garantias ${ }^{50}$.
\end{abstract}

\footnotetext{
49 “Art. 6. São direitos básicos do consumidor: [...] XI - a garantia de práticas de crédito responsável, de educação financeira e de prevenção e tratamento de situações de superendividamento, preservado o mínimo existencial, nos termos da regulamentação, por meio da revisão e repactuação da dívida, entre outras medidas; XII - a preservação do mínimo existencial, nos termos da regulamentação, na repactuação de dívidas e na concessão de crédito."

50 BRASIL. Câmara dos Deputados. Projeto de Lei n. 3.515/2015. Autor: Senado Federal - José Sarney PMDB/AP. Altera a Lei no 8.078, de 11 de setembro de 1990 (Código de Defesa do Consumidor), e o art. 96 da Lei ${ }^{\circ} 10.741$, de $1^{\circ}$ de outubro de 2003 (Estatuto do Idoso), para aperfeiçoar a disciplina do crédito ao consumidor
} 
Em complemento a disciplina do artigo 54-E, o anteprojeto também apresenta a possibilidade de o próprio consumidor ter a iniciativa de concitar os credores a repactuarem prestações e cláusulas contratuais, com o objetivo de angariar melhores condições de solvência e soerguimento. Assim, os artigos 104- $\mathrm{A}^{51}$ e 104-B ${ }^{52}$ da proposição apresentam um regramento que segue uma lógica parecida à da recuperação judicial disciplinada na Lei n. 11.101/05, permitindo ao consumidor a apresentação de um plano de pagamento com previsão para cumprimento no prazo de cinco anos, cujos principais aspectos a serem conciliados serão a preservação do mínimo existencial e a satisfação do crédito.

Os dispositivos fazem ressalva expressa que o deferimento do processamento do plano de pagamento não importará em insolvência civil, garantindo expressamente a não incidência desta disciplina, ao menos em um primeiro momento ${ }^{53}$. Também, ao contrário do procedimento do Código Buzaid, a proposta legislativa não torna consequência obrigatória do deferimento do plano de pagamento a nomeação de um administrador judicial para gerenciar e arrecadar os bens do devedor, fato que só será cogitado na hipótese de a conciliação não ser exitosa e, ainda assim, desde que não culmine na oneração das partes ${ }^{54}$. Essas ressalvas se fazem importantes, pois articulam o procedimento de cobrança de dívidas às particularidades do mercado de consumo, proporcionando condições para resguardar a autonomia e a autodeterminação do consumidor.

e dispor sobre a prevenção e o tratamento do superendividamento. Situação: Pronta para Pauta no Plenário (PLEN); Pronta para Pauta na Comissão Especial destinada a proferir parecer ao Projeto de Lei n ${ }^{\circ} 3515$, de 2015, do Senado Federal, que "altera a Lei no 8.078, de 11 de setembro de 1990 (Código de Defesa do Consumidor), e o art. 96 da Lei $\mathrm{n}^{\circ} 10.741$, de $1^{\circ}$ de outubro de 2003 (Estatuto do Idoso), para aperfeiçoar a disciplina do crédito ao consumidor e dispor sobre a prevenção e o tratamento do superendividamento", e apensados (PL351515). Brasília, DF: Câmara dos Deputados, 4 nov. 2015. 4 Disponível https://www.camara.leg.br/proposicoesWeb/fichadetramitacao?idProposicao=2052490. Acesso em: 30 mar. 2021.

51 "Art. 104-A. A requerimento do consumidor superendividado pessoa natural, o juiz poderá instaurar processo de repactuação de dívidas, visando à realização de audiência conciliatória, presidida por ele ou por conciliador credenciado no juízo, com a presença de todos os credores, em que o consumidor apresentará proposta de plano de pagamento com prazo máximo de 5 (cinco) anos, preservados o mínimo existencial, nos termos da regulamentação, e as garantias e as formas de pagamento originalmente pactuadas."

52 "Art. 104-B. Inexitosa a conciliação em relação a quaisquer credores, o juiz, a pedido do consumidor, instaurará processo por superendividamento para revisão e integração dos contratos e repactuação das dívidas remanescentes mediante plano judicial compulsório, procedendo à citação de todos os credores cujos créditos não tenham integrado o acordo porventura celebrado."

53 “Art. 104-A, $\S 5^{\circ} \mathrm{O}$ pedido do consumidor a que se refere o caput deste artigo não importa declaração de insolvência civil e poderá ser repetido somente após decorrido o prazo de 2 (dois) anos, contado da liquidação das obrigações previstas no plano de pagamento homologado, sem prejuízo de eventual repactuação.”

54 “Art. 104-B, $\S 3^{\circ} \mathrm{O}$ juiz poderá nomear administrador, desde que isso não onere as partes, o qual, no prazo de até 30 (trinta) dias, após cumpridas as diligências eventualmente necessárias, apresentará plano de pagamento contemplando medidas de temporização ou atenuação dos encargos." 
Também é digno de nota que o dispositivo em referência, ao consignar que o plano de pagamento deverá prever a repactuação das dívidas com a concessão dilação de pagamentos, redução dos encargos da dívida ou da remuneração do fornecedor; suspensão ou extinção das ações judiciais; assim como a possibilidade de exclusão do consumidor de bancos de dados e cadastro de inadimplentes, impõe como condição de procedibilidade o compromisso do beneficiário adotar medidas que não importem o agravamento da situação de superendividamento ${ }^{55}$. Este compromisso, por certo, reforça o caráter preventivo que deve ser dispensado às situações de endividamento excessivo, acentuando a importância do direito básico à informação, em especial por meio das estratégias de educação financeira, além de conferir maior expressão ao princípio da lealdade contratual em favor dos credores.

Sem o objetivo de esgotar ponto a ponto a proposta legislativa, é visível que as disposições tendem a resgatar a dignidade do consumidor, porquanto abrem novo horizonte à repactuação dos negócios e à preservação do mínimo vital, permitindo que o particular se reinsira e se mantenha no mercado de consumo. Como dito, o espírito do PL 3.515/2015 mais do que altera a Lei 8.078/1990, mas também promove o aperfeiçoamento da disciplina do crédito, a regulação da prevenção e do tratamento do superendividamento, assim como apresenta uma proposta alternativa para a solução dos desencontros que o consumo(mismo) foi capaz de criar entre 'ter' e 'ser' que atualmente condicionam as mazelas da era do hiperconsumo ${ }^{56}$. Em direção semelhante, Karen Bertoncello também reforça a pertinência da proposta legislativa, mormente no tocante ao incentivo à institucionalização das práticas de mediação e conciliação:

[o] texto endereça tutela aos consumidores pessoas físicas e institucionaliza em nosso ordenamento jurídico as práticas já realizadas no Poder Judiciário dos Estados do Rio Grande do Sul, Paraná, Pernambuco e São Paulo, facultando a realização da audiência de conciliação por conciliador sob a coordenação do Juiz de Direito. Aspecto positivo sobre a inserção destas práticas no CDC é o estímulo à expansão deste atendimento no Poder Judiciário e demais parceiros, pois, os frutos colhidos ao longo de seis anos

\footnotetext{
55 “Art. 104-A. [...] $§ 4^{\circ}$ Constarão do plano de pagamento: I - medidas de dilação dos prazos de pagamento e de redução dos encargos da dívida ou da remuneração do fornecedor, entre outras destinadas a facilitar o pagamento das dívidas; II - referência à suspensão ou extinção das ações judiciais em curso; III - data a partir da qual será providenciada a exclusão do consumidor de bancos de dados e cadastros de inadimplentes; IV - condicionamento de seus efeitos à abstenção, pelo consumidor, de condutas que importem o agravamento de sua situação de superendividamento."

56 CARVALHO, Diógenes Faria de; FERREIRA, Vitor Hugo do Amaral. Consumo(ismo) e (super)endividamento: (des)encontros entre a dignidade e a esperança. In: MARQUES, Claudia Lima; CAVALlAZZI, Rosângela; LIMA, Clarissa Costa de (coords.). Direitos do Consumidor endividado II: vulnerabilidade e inclusão. São Paulo: Revista dos Tribunais, v. 2, p. 171-198, 2016. p. 195.
} 
de execução deste serviço tem revelado a efetividade desta prática de solução pacífica de conflitos ${ }^{57}$.

Todas estas medidas veiculadas na iniciativa parlamentar se compatibilizam com a incidência direta e imediata dos direitos fundamentais nas relações de consumo. Essas proposições permitem não só que os contratantes solucionem os conflitos oriundos da relação jurídica consumerista consensualmente, como também reserva ao Poder Judiciário a possibilidade de intervir com parâmetro legislativo específico, reduzindo a insegurança causada pela jurisprudência e pela lacuna legislativa.

\section{CONCLUSÃO}

A Constituição Federal de 1988 inovou ao garantir ao consumidor a proteção do Estado, assim como ao prever que a sua proteção será princípio da ordem econômica. Esta inovação impõe ao intérprete uma releitura do Direito do Consumidor à luz dos direitos individuais, a fim de garantir a incidência das normas constitucionais às relações particulares, preservando o mínimo existencial.

O superendividamento se mostra na sociedade contemporânea como um importante fator causador de exclusão social. Isso porque, ao sujeitar o consumidor à situação análoga a uma "morte civill", restringe a sua participação na sociedade, o excluindo do mercado de consumo. O que agrava a relevância do fenômeno é o fato de que, muitas vezes, o indivíduo se vê nesta situação em virtude de acontecimentos da vida, que o acabam colocando involuntariamente em situação de insolvência. Embora a Carta Republicana tenha ampliado a proteção constitucional dos direitos do consumidor, a legislação infraconstitucional não dispõe de alternativas efetivas ao superendividamento. Segundo o que dispõe o CPC, o estado de insolvência da pessoa física poderá ensejar a adoção da execução universal, implicando na retirada do consumidor da administração dos seus bens.

Alternativamente ao procedimento da insolvência, há a possibilidade de aviamento de ação judicial de revisão de cláusulas contratuais fundada na teoria da onerosidade excessiva. Contudo, a lacuna legislativa impõe obstáculos à efetividade da tutela jurisdicional, especialmente diante da necessidade de socorrer a métodos de integração da norma e da

57 BERTONCELLO, Káren Rick Danilevicz. Breves linhas sobre o estudo comparado de procedimentos de falência dos consumidores França, Estados Unidos da América e anteprojeto de lei no Brasil. Revista de Direito do Consumidor, São Paulo, v. 83, p. 113-140, jul./ set. 2012. p. 133. 
ausência de parâmetro certo para fixação do percentual mínimo de renda como suficiente para garantir o mínimo vital. Nesta medida, a ausência de regramento específico sobre a matéria e o estado de insegurança jurídica criada pelos precedentes dos tribunais superiores acaba por impor obstáculo de difícil superação ao direito de acesso à justiça do consumidor superendividado. A busca pelos meios alternativos de solução de conflitos, enquanto não atualizadas as normas do CDC no ponto específico do superendividamento, se mostra como uma saída crível à problemática, especialmente por meio da institucionalização de programas de orientação preventiva do consumidor, nos moldes já executados pelos Tribunais de Justiça do Estado do Rio Grande do Sul e do Distrito Federal e Territórios.

Destaca-se que as experiências positivas reveladas pelas iniciativas destes tribunais demonstram que a conciliação articulada do consumidor com os seus credores, por meio da repactuação livre e consciente das dívidas, pode ser um caminho ainda mais efetivo que a própria atuação definitiva da jurisdição. Isso porque, nessas práticas, se prioriza a autonomia da vontade dos contratantes, balizados pela função social do contrato, além de se promover práticas de educação financeira voltadas à prevenção do endividamento excessivo.

A instabilidade jurídica que paira sobre o consumidor em superendividamento impõe a atuação do legislador brasileiro rumo à atualização do CDC. Nesse sentido, o PL 3.515/15 avança ao positivar o conceito de superendividamento também quando insere o mínimo existencial como bem jurídico a ser tutelado pelo Estado, assim como ao primar por métodos de prevenção, informação, conciliação e mediação como alternativa à repactuação e renegociação de encargos contratuais. Do mesmo modo, há inequívoco avanço nas previsões concernentes ao plano de pagamento a ser apresentado pelo consumidor em primazia às normas da insolvência civil dispostas no CPC de 1973, porquanto concede um fôlego maior para o pagamento das dívidas sem implicar na adoção de medidas mais invasivas que onerem ao ponto de causar a exclusão deste do mercado de consumo.

\section{REFERÊNCIAS}

BERTONCELLO, Káren Rick Danilevicz; COSTA DE LIMA, Clarissa. Adesão ao projeto conciliar é legal - CNJ projeto-piloto: tratamento das situações de superendividamento do

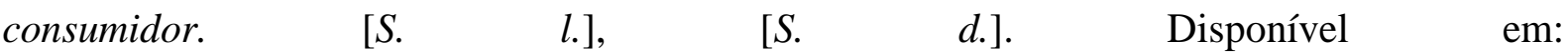
https://www1.tjrs.jus.br/export/processos/conciliacao/doc/projeto_superendividamento.pdf. Acesso em: 29 mar. 2021. 
BERTONCELLO, Káren Rick Danilevicz. Breves linhas sobre o estudo comparado de procedimentos de falência dos consumidores França, Estados Unidos da América e anteprojeto de lei no Brasil. Revista de Direito do Consumidor, São Paulo, v. 83, p. 113-140, jul./ set. 2012.

BRASIL. Câmara dos Deputados. Projeto de Lei n. 3.515/2015. Autor: Senado Federal - José Sarney - PMDB/AP. Altera a Lei no 8.078, de 11 de setembro de 1990 (Código de Defesa do Consumidor), e o art. 96 da Lei $\mathrm{n}^{\circ} 10.741$, de $1^{\circ}$ de outubro de 2003 (Estatuto do Idoso), para aperfeiçoar a disciplina do crédito ao consumidor e dispor sobre a prevenção e o tratamento do superendividamento. Situação: Pronta para Pauta no Plenário (PLEN); Pronta para Pauta na Comissão Especial destinada a proferir parecer ao Projeto de Lei $\mathrm{n}^{\mathbf{0}} 3515$, de 2015, do Senado Federal, que "altera a Lei ${ }^{\circ}$ 8.078, de 11 de setembro de 1990 (Código de Defesa do Consumidor), e o art. 96 da Lei $\mathrm{n}^{\mathrm{o}} 10.741$, de $1^{\circ}$ de outubro de 2003 (Estatuto do Idoso), para aperfeiçoar a disciplina do crédito ao consumidor e dispor sobre a prevenção e o tratamento do superendividamento", e apensados (PL351515). Brasília, DF: Câmara dos Deputados, 4 nov. 2015.

Disponível

em: https://www.camara.leg.br/proposicoesWeb/fichadetramitacao?idProposicao=2052490. Acesso em: 30 mar. 2021.

BRASIL. Senado Federal. Projeto de Lei do Senado n. 1.166/20. Autor: Senador Alvaro Dias - PODEMOS/PR. Estabelece teto de $20 \%$ ao ano para todas as modalidades de crédito ofertadas por meio de cartões de crédito e cheque especial para todas as dívidas contraídas entre os meses de março de 2020 e julho de 2021. Situação: tramitação encerrada. Disponível em: https://www25.senado.leg.br/web/atividade/materias/-/materia/141297. Acesso em: 30 mar. 2021.

BRASIL. Superior Tribunal de Justiça. REsp 1.584.501/SP. Rel. Ministro Paulo de Tarso Sanseverino, Terceira Turma. Julgado em: 06 de outubro de 2016. DJe de 13 de outubro de 2016.

BRASIL. Superior Tribunal de Justiça. REsp 1.586.910/SP. Rel. Ministro Luis Felipe Salomão, Quarta Turma. Julgado em: 29 de agosto de 2017. DJe de 03 de outubro de 2017.

BRASIL. Tribunal de Justiça do Estado de Goiás. Agravo de Instrumento n. 546777674.2019.8.09.0000. Rel. Francisco Vildon José Valente. 5a Câmara Cível. Julgado em: 18 de novembro de 2019, DJe de 18 de novembro de 2019.

BRAUNER, Daniela Corrêa Jacques. Estudo, mercado e defesa do consumidor: uma leitura da proteção constitucional ao consumidor superendividado à luz da intervenção do Estado na ordem econômica. Revista de Direito do Consumidor, São Paulo, v. 96, n. 24, nov./dez. 2014. 
BUCAR, Daniel. Superendividamento: reabilitação patrimonial da pessoa humana. São Paulo: Saraiva, 2017.

CÂMARA, Alexandre Freitas. Lições de Direito Processual Civil. v. 2. $23^{\mathrm{a}}$ ed. São Paulo: Atlas, 2014.

CAPELETTI, Mauro; GARTH, Bryan. Acesso à justiça. Tradução de Ellen Gracie Northfleet. Porto Alegre: Fabris, 1998.

CARVALHO, Diógenes Faria de, OLIVEIRA, Amanda Flávio. Vulnerabilidade comportamental do consumidor: por que é preciso proteger a pessoa superendividada? In: MIRAGEM, Bruno; MARQUES, Claudia Lima; OLIVEIRA, Amanda Flávio de (coords.). 25 anos do Código de Defesa do Consumidor: trajetória e perspectiva. São Paulo: Editora Revista dos Tribunais, 2016, p. 527-548.

CARVALHO, Diógenes Faria de; FERREIRA, Vitor Hugo do Amaral. Consumo(ismo) e (super)endividamento: (des)encontros entre a dignidade e a esperança. In: MARQUES, Claudia Lima; CAVALLAZZI, Rosângela; LIMA, Clarissa Costa de (coords.). Direitos do Consumidor endividado II: vulnerabilidade e inclusão. São Paulo: Revista dos Tribunais, v. 2, p. 171-198, 2016.

CARVALHO, Diógenes Faria de; SANTOS, Nivaldo. A vulnerabilidade psíquica e o superendividamento do consumidor. In: CARVALHO, Diógenes Faria; SANTOS; Nilvaldo; FERREIRA, Vitor Hugo do Amaral (orgs.). Sociedade de Consumo: pesquisas em direito do consumidor. Goiânia: Espaço Acadêmico, 2015, p. 89-112.

CASADO, Márcio Mello. Os princípios fundamentais como ponto de partida para uma primeira análise do sobre-endividamento no Brasil. Revista de Direito do Consumidor, São Paulo, v. 33, p. 130-140, 2000.

COSTA, Geraldo de Faria Martins. Superendividamento: a proteção do consumidor de crédito em direito comparado brasileiro e francês. São Paulo: Editora Revista dos Tribunais, 2002.

DISTRITO FEDERAL. Tribunal de Justiça do Distrito Federal e dos Territórios. Portaria 49, de 16 de dezembro de 2014. Institui o Programa de Prevenção e Tratamento de Consumidores Superendividados - SUPERENDIVIDADOS, no âmbito dos Centros Judiciários de Solução de Conflitos e Cidadania - CEJUSCs, vinculados ao Núcleo Permanente de Mediação e Conciliação - NUPEMEC. Brasília, DF: Gabinete da Segunda Vice-Presidência, 22 dez. 2014. Disponível em: https://www.tjdft.jus.br/publicacoes/publicacoes-oficiais/portariasgsvp/2014/portaria-gsvp-48-17-12-2014. Acesso em: 29 mar. 2021. 
DUQUE, Marcelo Schenk. O dever fundamental do Estado de proteger a pessoa da redução da função cognitiva provocada pelo superendividamento. Revista de Direito do Consumidor, São Paulo, v. 73, p. 157-179, 2014.

GONÇALVES, Carlos Roberto. Direito Civil Brasileiro: Contratos e Atos Unilaterais. São Paulo: Saraiva, 2014.

GONÇALVES, Geyson. $O$ superendividamento e o mínimo existencial: uma abordagem garantista. 2016. 216 f. Tese (Doutorado em Direito) - Faculdade de Direito, Universidade Federal de Santa Catarina, Florianópolis, 2016.

KILBORN, Jason J. Comportamentos Econômicos, superendividamento; estudo comparativo da insolvência do consumidor: buscando as causas e avaliando soluções. In: MARQUES, Claudia Lima; CAVALLAZZI, Rosângela (coords.). Direitos do Consumidor Endividado: superendividamento e crédito. São Paulo: Editora Revista dos Tribunais, 2006, p. 66-104.

LEITÃO MARQUES, Maria Manuel. O endividamento dos consumidores. Lisboa: Almedina, 2000 .

LIMA, Clarissa Costa de; BERTONCELLO, Káren Rick Danilevicz; MARQUES, Claudia Lima. Anteprojeto de lei dispondo sobre a prevenção e o tratamento das situações de superendividamento de consumidores pessoas físicas de boa-fé. Revista de Direito do Consumidor, São Paulo, v. 73, p. 345-367, 2010.

LOPES, José Reinaldo de Lima. Crédito ao consumo e superendividamento: uma problemática geral. Revista de Direito do Consumidor, São Paulo, v. 17, p. 57-64, jan./mar, 1996.

MARQUES, Cláudia Lima. Algumas perguntas e respostas sobre a prevenção e tratamento do superendividamento dos consumidores pessoas físicas Revista de Direito do Consumidor, São Paulo, v. 75, n. 9, 2010.

MARQUES, Claudia Lima. Consumo como igualdade e inclusão social: a necessidade de uma lei especial para prevenir e tratar o "superendividamento" dos consumidores pessoas físicas. Revista Jurídica da Presidência, Brasília, DF, v. 13. n. 101, p. 405-424, out. 2011/jan. 2012.

MARQUES, Claudia Lima. Contratos no Código de Defesa do Consumidor: O novo regime das relações contratuais. $3^{\text {a }}$ ed. São Paulo: Editora Revista dos Tribunais, 1999.

MARQUES, Claudia Lima. Sugestões para uma lei sobre o tratamento do superendividamento de pessoas físicas em contratos de crédito ao consumo: proposições com base em pesquisa empírica de 100 casos no Rio Grande do Sul. In: MARQUES, Claudia Lima; CAVALLAZZI, 
Rosângela Lunardelli (coords.). Direitos do consumidor endividado: superendividamento e crédito. São Paulo: Editora Revista dos Tribunais, 2006, p. 255-309.

OLIVEIRA, Janaína. Empréstimo Consignado dispara na crise. Hoje em dia, Belo Horizonte, 17 maio 2015. Disponível em: http://www.hojeemdia.com.br/noticias/economia-enegocios/empréstimo-consignado-dispara-na-crise-1.318637. Acesso em: 31 mar. 2021.

Paulo, v. 33, p. 130-140, 2000.

REVERBEL, Carlos Eduardo Dieder. Drittwirkung e ADI dos bancos: a proteção fundamental do consumidor ao não superendividamento. Revista de Direito do Consumidor, São Paulo, a. 26, v. 110, p. 17-57, mar./abr., 2017.

SARLET, Ingo. A Eficácia do Direito Fundamental à Segurança Jurídica: dignidade da pessoa humana, direitos fundamentais e proibição de retrocesso social no Direito Constitucional Brasileiro. Revista Eletrônica sobre a Reforma do Estado (RERE), Salvador, Instituto Brasileiro de Direito Público, n. 21, mar./maio, 2010. Disponível em: http://www.direitodoestado.com.br/rere/edicao/21. Acesso em: 29 mar. 2021.

SARLET, Ingo. A eficácia dos direitos fundamentais. $2^{\mathrm{a}}$ ed. Porto Alegre: Livraria do Advogado, 2001.

SARLET, Ingo. Direitos fundamentais sociais, mínimo existencial e direito privado. Revista de Direito do Consumidor, São Paulo, v. 61, jan./mar., p. 90-125, 2007.

SILVA, José Afonso da. Curso de Direito Constitucional positivo. $23^{a}$ ed. São Paulo: Malheiros, 2004.

WATANABE, Kazuo. Acesso à justiça e sociedade moderna. In: GRINOVER, Ada Pellegrini et al. Participação e processo. São Paulo: Revista dos Tribunais, 1998, p. 128-135.

\section{DADOS DA PUBLICAÇÃO}

Categoria: artigo submetido ao double-blind review.

Recebido em: 29/09/2020.

Aceito em: 05/04/2021. 
